Bilgi (27), 2013 Kış / Winter : $103-120$

\title{
Fostering of Civil Society by Muslim Women's NGO-s in Bosnia and Herzegovina
}

\author{
Muhidin Mulalic ${ }^{1}$
}

\begin{abstract}
The fostering of civil society is vital in multiethnic, multicultural, multi-religious and post-conflict societies such as that of BosniaHerzegovina. Therefore, this paper examines the role of Muslim women's Non Government Organisations (NGOs) in fostering civil society in BosniaHerzegovina. In this regard, this paper puts in perspective the present role of Muslim women's NGOs by providing the theoretical background and a survey of NGOs in Bosnia-Herzegovina. In order to determine the role and function of Muslim women's NGOs, the author examines the main criteria of civil society functions such as control of political power, monitoring of political participation and elections, promoting anti-corruption awareness, advocating values of human rights, tolerance and understanding, offering civic training, promoting civic education and public issues through media, and promoting conflict resolution and inter-faith dialogue. By analyzing civil society functions this paper answers the question of Muslim women's NGOs involvement in socio-political aspects of a democratic state and fostering of civil society in Bosnia-Herzegovina. The author uses an ethnographic methodology, written sources and interviews in analyzing two leading Muslim Women's NGOs such as Nahla Education Center for Women and Kewser-Zehra Association of Muslim Women. The results of this paper indicate that although Muslim women's NGOs in theory do not meet some of the criteria to be considered a civil society actor, especially those of a political and legal nature, they are, nonetheless, significantly involved through their various activities in sociopolitical aspects of the democratic state and, as such, they have contributed significantly towards fostering of civil society in Bosnia-Herzegovina.
\end{abstract}

Keywords: Muslim Women's NGO-s, State-building, Socio-politics, Civil Society and Bosnia and Herzegovina

${ }^{1}$ Assist. Prof. Dr. International University of Sarajevo 


\section{Introduction}

This paper introduces readers to the role of NGOs in democracy and civil society building in Bosnia-Herzegovina. However, special emphasis is placed on the challenges and prospects of Muslim women's NGOs and their possible contributions towards the emergence of socio-political aspects of a democratic state in Bosnia-Herzegovina. Therefore, the emergence and flourishing of NGOs has been particularly popular in Bosnia-Herzegovina as well as, in other emerging democratic states worldwide. This is especially the case with post-conflict states that are in the process of conflict resolution, peacebuilding and state-building, a process Bosnia-Herzegovina has been going through since signing of the Dayton Peace Agreement.

Bosnia-Herzegovina has a long tradition of multicultural, multiethnic and multi-religious coexistence; and civil society values are deeply rooted in its history, culture and religion. Being at the crossroads of the oriental and occidental worlds and due to the spreading of different cultures, civilizations and religions, Bosnia-Herzegovina reflects diverse socio-political values (Donia and Fine, 1994: 86). Turbulent past historical experiences of Bosnia-Herzegovina also indicates that states, cultures, civilizations and religions respectively clash, meet and coexist; a process that is inevitable for historical progress and dynamism (Mulalić, 2009: 109-126; Mahmutčehajić, 2000: 183-190; Imamovic, 2006: 44-48; Velikonja, 2003: 19 and Noel, 1994: 27-42). Therefore, it is important to analyze recent notions and understandings of the historicity of Bosnia-Herzegovina, the functioning of the NGO sector and fostering of civil society. There are numerous studies on the role of NGOs in Bosnia-Herzegovina, however very few studies have been devoted to the role of Muslim women's NGOs in fostering civil society. Besides, such exclusive studies have only considered the religious, welfare and humanitarian role of Muslim women's NGOs whereby their possible sociopolitical involvement in the democratic state has often been overlooked.

Apart from clearly mentioned research objectives in the abstract, this paper aims to present the role of NGOs in Bosnia-Herzegovina towards the process of transition, democratization and normalization. An attempt has been made to remove the widely spread images of war often associated 
Fostering of Civil Society by Muslim Women's... 105

with Bosnia-Herzegovina and to put in the perspective a multicultural civil society and the positive role of NGOs in the final process of civil society building. Besides, notions of women's NGOs and associations are rather recent phenomena throughout the Muslim world, especially in BosniaHerzegovina. Therefore this pioneering paper attempts to articulate the significance of Muslim women's active and organizational role in sociopolitical aspects of the democratic state. In order to put into perspective the main scope of this papers research, it introduces readers to the conception of NGOs in post-conflict states and describes objectives of two leading Muslim women's NGOs in Bosnia-Herzegovina.

This paper is based on an ethnographic methodology, written sources, interviews and direct observation of the local Muslim women's NGOs. An attempt has been made to tackle key questions that would indicate Muslim women's socio-political involvement in the democratic state. These questions, for instance include: What are the similarities and differences between Muslim women's NGOs, being 'Islamic" and other NGOs, being 'civil or secular'? To what extent have Muslim women's NGOs been involved in analyzing, criticizing and opposing the views and policies of political powers? In what ways and to what extent have Muslim women's NGOs been involved in political participation and election campaigns? Have Muslim women's NGOs been involved in interfaith dialogue and fostering of tolerance and understanding? Have Muslim women's NGOs been involved in the promotion of civic education, human rights and civic training? Do Muslim women's NGOs offer to the public training, workshops, seminars and conferences that could eventually contribute towards civil society building? (Sejfija, 2006: 126).

\section{The Conception of NGOs in Post-Conflict States}

From the mid $19^{\text {th }}$ century NGOs have been successfully operating and the term itself began to be used more frequently after the World War II, a period that indeed reflected the need of NGOs in fostering of the civil society. Since then NGOs, as independent societal organizations, began first focusing on assistance and social care services in terms of the distribution of food, shelter and medical assistance. In the following decades due to vari- 
ous needs, NGOs expanded their scope from mere assistance to capacity building in terms of education and training. During the past decade or so NGOs have promoted political and institutional changes and development at local, national and international levels due in part to the democratization process (Boli and Thomas, 1997: 171-190 and Martens, 2002: 271-285). Therefore globalization and democratization have contributed to the growing importance of NGOs worldwide and, as a result, the conception of the civil society was also popularized.

Since beginning of the war in Bosnia-Herzegovina, the socialist structured NGO sector began to change and transform rapidly. It is important to mention that when the Yugoslav crisis emerged socialist civil society was unable to counter the spreading of nationalism which was one of the major causes that contributed to conflicts in the early 1990s. Newly established NGOs in Bosnia-Herzegovina with the assistance of international organizations and actors in 1990s were focusing mostly on humanitarian assistance and social care services. However after signing of the Dayton Peace Agreement, NGOs began to play significant roles in peace-building, postwar trauma support and the reintegration of the country (Sejfija, 2006: 125). Nowadays, NGOs take an active role in the monitoring of political leadership, political participation and elections, advocating anti-corruption awareness, promoting values of tolerance and understanding, civic education and human rights, and promoting of public issues. Thus, any post-war country, including Bosnia-Herzegovina, goes through three phases of development namely: peace-building and elections, state-building and civil society building (Deacon and Stubbs, 1998: 99-115).

NGOs played a positive role in bridging deeply divided ethnic groups namely Bosniaks, Croats and Serbs. For instance prior to the beginning of war on April 5, 1992 NGOs organized peace demonstrations that were aimed at preventing the war; however Serb paramilitary units fired on the protesters. Then, NGOs and civil society played significant role in the final settlement in Dayton in 1995 (Belloni, 2010: 129-153). Even after the war quite many NGOs attempted to keep multi-ethnicity alive such as Circle 99, Young Bridge, Sezam, the Citizens' Alternative Parliament and Tuzla Citizens' Forum (Belloni, 2010: 164). Actually such activities of local NGOs were sup- 
Fostering of Civil Society by Muslim Women's... 107

ported by the UN and international organizations because they were not only significant for the development of a democratic culture of tolerance, moderation and compromise but they inevitably contributed towards a democratization process in Bosnia-Herzegovina (Chandler, 1998: 1-20).

Since the 1990s, NGOs in Bosnia-Herzegovina were heavily dependent on international donors. Newly established NGOs were overemphasizing new western models in terms of organization, structure and scope (Hemmer, 2008: 71-111). The role of NGOs that existed in Bosnia-Herzegovina before the war was entirely neglected. As a result, local NGOs were involved in staff training and the development of projects that had very little connection with local social, economic and political realities. Quite often certain NGOs were accused of focusing more on international projects and the demands of donors than on the demands of civil society (Sejfija, 2006: 134-136). The above-mentioned priorities were determined by donors who were mostly applying their western perceptions without considering local conditions. International donors also conditioned local NGOs to integrate multiethnic representation, gender and activities within the scope of their organizations (Belloni, 2007: 109-112). As mentioned in the above, civil society was promoted by international donors as a path towards democratization and the establishment of a unified multiethnic and multicultural state of Bosnia-Herzegovina.

The period from the 1990s saw the excessive emergence of nationalism all over the Balkans and especially in Bosnia-Herzegovina where different ethnic communities for centuries were living side-by-side. Yugoslavian "brotherhood and unity" and socialist political culture were replaced by ethno-nationalistic ideologies. Therefore, the early phase of the establishment of NGOs was characterized by the ethno-nationalistic outlook of NGOs. Nowadays certain NGOs are also emphasizing "ethno-nationalism" that is further dividing and destabilizing the country. Such NGOs are often supported by ethno-nationalist political leaders whose nationalistic rhetoric and obstructionist attitude remain as a serious problem for a civil society state-building project that attempts to foster multiculturalism and coexistence amongst different ethnic groups in Bosnia-Herzegovina. In fact, excessive ethno-nationalism was a major obstacle for the consolidation of 
democracy in other post-communist countries undergoing transition like that of Bosnia-Herzegovina (Helms, 2010: 17-32).

Women's organizations in Bosnia- Herzegovina have been particularly active in the provision of protective functions during and after the war. NGOs such as Women to Women, La Strada, the International Forum of Solidarity, Lara, Medica Zenica and the Future were helping women's victims by providing shelter, healthcare services, counseling and legal assistance. Besides these functions, their activities have also been aimed at the establishment of a stable multiethnic state in Bosnia-Herzegovina. Women were the first to cross the ethnic boundaries and contributed to reconciliation of ethnonational groups (Helms, 2003: 15-33 and Helms, 2003: 85). Moreover, donors have especially targeted women with projects of ethnic reconciliation and the reestablishment of cross-ethnic communication. For instance, Medica Women's Association and Women to Women NGOs were directly propagating "men make war, women make peace." (Cockburn, et. al., 2001: 40-42).

In the past decade secular women's NGOs have transformed their activities from the mere offering of social and humanitarian services to offering a range of activities that deal with the economic position of women, the advocacy of women's political and public life, support against domestic violence and human trafficking, discrimination against women, gender equality and women's health and reproductive rights. Nowadays secular women's NGOs play significant role in the implementation of the Gender Action Plan of Bosnia-Herzegovina.

\section{Muslim Women's NGOs in Bosnia and Herzegovina}

The war in Bosnia-Herzegovina and the subsequent process of democratization created profound social, political and economic changes. In this regard, the Muslim women NGOs contributed significantly towards the construction and the development of the civil society. Such progress would have been impossible without the pressure from the NGO sector as government is less capable of tackling alone socio-political, legal and economic issues and challenges faced by the society at large (Lyon, 2006: 67).

Prior to the war in Bosnia-Herzegovina Muslim women were largely excluded from the affairs of civil society. Actually, their representation in the 
Fostering of Civil Society by Muslim Women's... • 109

religious institutions and associations was also very much limited. A widely spread stereotype of "backwardness" of the Muslim women also contributed towards a very inactive role on the part of Muslim women in civil society. During the socialist era an 'ideal' and 'modern' women was presented as uncovered, urban, educated and visible in the public sphere. This was contrary to the perceptions about the traditional Muslim women that were often presented as covered, uneducated, rural and anti-modern (Ballinger and Ghodsee, 2011: 6-27). However, newly established Muslim women's NGOs have significantly transformed the picture of Muslim women as one of being covered, educated and well positioned in society. Nowadays, visible Muslim women, characterized by their dress code, take an active role in society and they can be found working in schools, universities, state institutions and the private sector (http://www.miztuzla. com/content/view/452/39/). In Bosnia-Herzegovina there are several publically known and popular Muslim women who are characterized by their Muslim dress code; one of them is Mrs. Aida Begic a Director of the film "Snijeg [Snow]" that won the 2008 Cannes Critics' Week Grand Prize. Mrs. Begic and many other prominent Muslim women contributed towards gradual changing of the perceptions about the Muslim women.

In Bosnia-Herzegovina Muslim women who complete religious highschool or madrasah and Faculty of Theology, work in schools, kindergartens and religious schools as teachers. Also, some of them join Muslim women's NGOs and are involved in religious education and training. However, quite a few of them, especially those covered, face discrimination not only in state institutions and the private sector, but also partly in the institutions of the Islamic Community (Tahirovic, 2009: 26-35 and Šeta, 2011: 161-163). In this regard, apart from Muslim women's limited role in the institutions of the Islamic Community, it is significant to mention that the Islamic Community in Bosnia-Herzegovina supports the activities of Muslim women's NGOs. For instance, the Islamic Community supported the Nahla Education Center for Women to get actively involved in institutionalizing counseling services in order to tackle violence in the Muslim family (http://www.islambosna.ba). The Islamic Community also supports Kewser-Zehra Association of Muslim Women to organize a cultural and re- 
ligious event known as "The Musk of the Prophet."

Being religious, Muslim women's NGOs mostly do not target Western donors for funds. Besides, Western donors entirely neglected religious NGOs considering them as being exclusive and against establishing a multiethnic state of Bosnia-Herzegovina. Therefore, Muslim women NGOs were forced to seek support from Islamic donors. However, Islamic donors as Western ones have their own agendas in terms of allocating donated resources and, thus, the promotion of specific objectives through Muslim women's NGOs. As a result, Muslim women's NGOs attempt to develop ways of self-sustenance through NGO membership and offering of services for the public at minimal cost (Helms, 2003: 88). It is significant to mention that very often different state ministries, such as Ministry of Civil Affairs, provide small financial support for NGOs including for Muslim women's NGO's.

During the past two decades Muslim women's NGOs in BosniaHerzegovina have made significant efforts in positioning of women within the socio-political, legal and economic aspects of society. As a result, feminism in Bosnia-Herzegovina has been mostly perceived within the religion of Islam (Badran, 2005: 6-28). Besides seeking a position for Muslim women within society, Muslim women's NGOs in Bosnia-Herzegovina do seek the reinterpretation of Islamic sacred sources like for instance Asma Barlas, Fatima Mernissi, Leila Ahmed and Amina Wadud. Being influenced by a secular notion of gender equality some Muslim women's NGOs in the Muslim world emphasize their liberal views that often don't have basis in the religion of Islam. However, Muslim women's NGOs in BosniaHerzegovina have not been involved in any religious controversial interpretation of the religion of Islam and, as a result, such NGOs have received acceptance and support by wider circles of the community. Muslim women's NGOs attempted to position themselves as being religious within the state's secular socio-political context as much as possible (Spahić-Šiljak and Jadranka Anic, 2009: 5-41). Considering the fact that family is the basis of society for most of Muslim women's NGOs in Bosnia-Herzegovina, they put special emphasis on an individual identity, a woman and traditional family values (Haddad, 1998: 12-21 and Badran, 2005: 14). 
Fostering of Civil Society by Muslim Women's... 111

Muslim women's NGOs are not foreign to Bosnia-Herzegovina as the first such organization "Osvitanje" was established in 1919 and its establishment was initiated by Muslim women intellectuals. This early NGO aimed at cultural and educational revival and an active role of Muslim women in public life; the integration of Muslim women in the economic aspect of life, women's employability and financial independence; preservation of moral and Islamic religious upbringing and education and emancipation and affirmation of women's rights and values (Kujrakovic, 2009: 156). However, nowadays among many others the two most influential Muslim women's NGOs are the Nahla Education Center for Women and Kewser-Zehra Association of Muslim Women.

In 2001, the Nahla Education Center for Women was established to "provide the space for Bosnian women in which they could feel safe and accepted and get a chance to learn, socialize, broaden and enrich their knowledge and acquire different skills needed to efficiently perform their jobs and actively participate in social life." With regards to its mission "Nahla is a Bosnian non-governmental organization dedicated to improve the quality of life and promote positive values in the society, providing education and support for women and family." Since its establishment Nahla has provided education services for hundreds of young girls and women regardless of their race, color, nationality or religion (www.nahla.ba). In order to fulfill its main program goals Nahla Education Center for Women is organized around a number of well-established departments such as the General Education Department, the Religious Education Department, the Women and Family Department, the Culture Department, the Life Skills Department, the Arts and Crafts Department, the Sports, Health and the Beauty Department and the Research Department.

Considering the unemployment rate, women's professional skills and women's financial dependence, the Nahla Education Center for Women offers a series of training programs. Such training programs provide comprehensive courses in the areas of administration, business correspondence and communication, book-keeping and accountancy, computer skills and foreign language courses. The Religious Education Department aims "to enhance spirituality of the faith, and to promote dialogue between cultures 
and religions." Therefore, in order to improve the community's very limited knowledge about the religion of Islam this department offers courses and lectures on the teaching of Islam, exegesis, traditions, scriptural recitation and interreligious meetings. The Women and Family Department aims "to contribute to women's personality and harmonization of marital and family relations, in cooperation with experts and specialized institutions." Therefore, this department offers individual and family counseling and seminars and workshops on parenting. The Cultural Department encourages the "fostering of the Bosnian culture, and establishment of different cultural institutions in Bosnia-Herzegovina and the world." Some of the cultural events include Remembrance Day that marks the Srebrenica massacre, exhibitions, book promotion and thematic evenings. The Life Skills Department aims "to encourage women to develop skills needed in business and everyday life." This department offers seminars and workshops on motivation, time-management, stress management, presentation skills, communication, teamwork and marketing. The Arts and Crafts Department is closely associated with the former Department as it enables women to improve certain skills such as painting, calligraphy, jewelry making and sewing. The Sports, Health and Beauty Department enhances the psychological and physical fitness of the women through the provision of sports and beautification services such as aerobics, fitness, pedicure, aromatherapy, massage and saunas. Finally, the Research Department aims to tackle socio-political and legal issues especially related to women. The priority of this department is research and public advocacy that focuses on women and family issues (http://www.family-resilience.com). As mentioned by its founder and Director, Mrs. Senija Dedic, 150-180 people seek assistance from Nahla Education Center on daily basis, which signifies the degree of activities undertaken by this NGO. Nahla is also extensively involved in working together with other organizations in fulfilling its objectives (http://www.islambosna.ba).

The Kewser-Zehra Association of Muslim Women got its name from the Arabic term "kewser," which means spring. This organization was founded in 1994 during the war and its name, therefore, signifies a struggle for survival of the Bosnian people during a very critical point of time in their his- 
Fostering of Civil Society by Muslim Women's... • 113

tory. The main aim of this NGO is to "help women and children in the field of education and growing up in the spirit of the Islamic faith and culture." The Kewser-Zehra Association of Muslim Women is involved in the publication of a bimonthly magazine Zehra, which derives inspiration from an ideal Muslim woman; Fatime ez-Zehre. She was mother, missionary of the religion of Islam, socio-political activist, supporter of the Prophet and of her husband Ali. Therefore, this magazine attempts to portray similar modern Bosnian Muslim women in this light (Oslobodjenje, September 5, 2010). In this regard, Zehra magazine deals with actual topics, illustrating the stories of successful covered women, highlighting women who pursue a professional career, publishes family interviews, profiles past Muslim women heroes and examines the socio-psychological aspects of life relating to women in general. In addition, the Kewser-Zehra Association of Muslim Women casts TV a program named TV Zehra that is boradcast on twelve different channels in Bosnia-Herzegovina and two channels abroad. Radio Zehra is broadcast twice a week on Radio Bir of the Islamic Community and is also the work of Kewser-Zehra Association of Muslim Women. This NGO also organizes seminars, roundtable discussions and lectures on various topics. Finally, each year the Kewser-Zehra Association of Muslim Women organizes a cultural and religious event known as "The Musk of the Prophet," to mark the birth of Hazrat Fatimah (www.zehra.ba).

\section{Muslim Women's NGOs}

\section{and Socio-Political Aspects of a Democratic State}

The above brief survey illustrates the very active role of Muslim women's NGOs. However, to what extent have Muslim women's NGOs been involved in the socio-political aspects of a democratic state and, thus, the fostering of civil society? This question will be elaborated further with reference to the key functions of civil society organizations such as control of political power, political participation and elections, anti-corruption awareness, values of tolerance and understanding, civic education and human rights, civic training, promotion of public issues through media, conflict resolution and inter-faith dialogue (Edwards, 2009: 1-17).

NGOs should play a vital role in the process of monitoring political 
power. In this regard NGOs have been extensively involved in analyzing, criticizing and opposing views and policies of political powers that are directly involved in governing the state of Bosnia-Herzegovina. With regards to the Muslim women's NGOs, monitoring of political power, political participation, corruption and election campaigns in Bosnia-Herzegovina are mostly excluded from the scope of their activities. Moreover, even when religious political issues, such as gender and family issues are publicly debated, the Muslim women's NGOs often do not participate in the process of public debates and the lobbying of political actors (Spahić-Šiljak, 2007: 204). The Nahla Education Center for Women Director Mrs. Sehija Dedovic holds that Muslim women's NGOs should take rather an active role in lobbying of state actors in order to adopt laws on; gender equality, the regulation of maternity, the protection of women's labor rights, the prevention of domestic violence (http://www.islambosna.ba). Furthermore, the Nahla Education Center for Women took an active role in the implementation of Gender Action Plan BiH (FIGAP). In 2010, considering the fact that significant numbers of women were still not aware of their rights and responsibilities, the Kewser-Zehra Association of Muslim Women, organized a seminar on the topic "Activism and Women." Some of the themes of the seminar even included "Political Lobbying and Active Participation in the Political Parties."

The Kewser-Zehra Association of Muslim Women covers political developments in the wider Muslim world, especially that of Palestine. Titles on this NGO's website include "Our Freedom is Incomplete without Palestinian Freedom," "Stolen and Occupied Land," "Arab World: Revolutions or Counterrevolutions," and "the US and the Developments in the Arab World," indicate that this NGO partly, though unconsciously, takes an active role in promoting political agendas. Perhaps, Islamic international donors played significant role in the appearance of such political agendas that are articulated also throughout the NGO's magazine, radio, TV and cultural events.

Obviously the role of civil society is to promote tolerance, moderation, compromise and respect for opposing views. Muslim women's NGOs have been directly involved in fostering tolerance and understanding in BosniaHerzegovina. In this regard the Nahla Education Center for Women has been extensively involved in organizing lectures, workshops and seminars on in- 
Fostering of Civil Society by Muslim Women's... 115

terreligious dialogue (Spahić-Šiljak and Jadranka Anic, 2009: 104). In 2009, the Nahla Education Center for Women organized a seminar titled "Interfaith Educational Meetings in Nahla." Then, in 2010 the TPO Foundation and Nahla Education Center for Women organized a workshop on the topic "Violence Doesn't Belong to Religion: Perspectives of Monotheistic Religions" (www.nahla.ba). Therefore, Muslim women's NGOs frequently play the role of mediating and resolving conflicts by providing programs, trainings, debates, seminars and workshops aimed at resolving the socio-political differences among major ethnic groups in Bosnia-Herzegovina.

The promotion of civic education, the protection of citizens against violence and the advocacy of human rights is another aspect of activity where NGOs play a significant role. Through their activities, the Nahla Education Center for Women and the Kewser-Zehra Association of Muslim Women have been extensively involved in the promotion, protection and advocacy roles. For instance, one of the program goals of the Nahla Education Center for Women is "to be a shelter for all women who need help, counsel or just warmhearted welcome and friendly environment." This NGO organizes professional counseling on various topics that deal with discrimination and family violence. In 2011 the Nahla Education Center for Women began research about the role of fathers in the raising of children titled "Asserting the Role of the Fathers in Preventing Domestic Violence" (Šeta and Dedovic). To fulfill this role the Kewser-Zehra Association of Muslim Women frequently organizes seminars in the field of journalism and media (Oslobodjenje September 5, 2010).

Civic training is a further role of civil society organizations. In this regard, both Muslim women's NGOs significantly emphasize on practically helping Muslim women to acquire various skills. Such short courses, workshops, seminars and conferences enable women to improve their skills in, for instance, management, business communication, marketing, painting, jewelry making and sewing.

In spite of the significant involvement of Muslim women's NGOs in the socio-political aspects of the democratic state and, thus, in their fostering of civil society in Bosnia-Herzegovina there are widely held views that Muslim women's NGOs are not active in fostering civil society. For instance, as 
Helms indicated "Terms like "civil society," "gender," "project proposal," "networking," etc. were conspicuously absent from these [Muslim women's NGOs] organizations' written and spoken rhetoric" (Helms, 2003: 87). A similar view is held by Zilka Spahić-Šiljak (2006: 204) who declares:

Such organizations are, therefore, generally not visible in the public arena in the processes of lobbying and advocacy, nor in the demonstration of those principles to which they are dedicated. To give an example, such religious organizations were not seen to participate in the preparation and lobbying for the Law on Gender Equality of Bosnia and Herzegovina, the Law on Protection from Domestic Violence, or other laws, as were numerous of the secular organizations, without whose participation and advocacy such laws would still today not have been adopted.

Being Muslim women's NGOs it is obvious that such NGOs operate within the Islamic framework and are involved excessively in religiously colored activities that are often, in turn, socio-political and civic in nature. Therefore the above mentioned activities point to significant involvement of Muslim women's NGOs in socio-political aspects of the democratic state and, thus, in fostering of civil society. This is contrary to an exclusive view that Muslim women's NGOs were not at all involved in socio-political aspects of the democratic state and, as such, don't foster civil society in Bosnia-Herzegovina.

\section{Concluding Remarks}

This paper indicates that Muslim women's NGOs in Bosnia-Herzegovina focus on gender-related issues within a traditional Islamic context. Their main objective is to enable Muslim women to play an active and autonomous role in society. Apart from emphasizing an Islamic identity and the family role of Muslim women, Muslim women's NGOs in BosniaHerzegovina have contributed significantly towards civil society building.

In essence Muslim women's NGOs do not directly articulate their sociopolitical contributions towards the development of a democratic state and, thus, the fostering of civil society. Socio-political notions are also entirely excluded from their mission, aims and objectives. Moreover, very often it appears that their activities, though being socio-political and civic in nature, 
Fostering of Civil Society by Muslim Women's... 117

are being simply presented as religious and humanitarian. However, the actual role and the diversity of functions carried out by these NGOs clearly indicate the socio-political involvement of Muslim women's NGOs. Therefore, Muslim women's NGOs, by operating within a secular context, through their active agency contribute significantly towards civil society building in Bosnia-Herzegovina.

Muslim women's NGOs should undergo significant transformation from mere emphasis on religious and humanitarian activities to greater involvement in socio-political aspects of the democratic state. In fact, there is a need on their part to articulate socio-political aspects because, in effect, quite many activities of Muslim women's NGOs are already socio-political in nature. Therefore, although Muslim women's NGOs operate within a secular framework there is room for articulating the socio-political aspects of life without violating the main principles of the religion of Islam. Such a paradigm shift would inevitably bring to light, institutionally, the sociopolitical concerns of Muslims.

Özet: Bosna Hersek’te olduğu gibi çok etnikli, çok kültürlü ve çok dinli toplumların çatışma sonrası süreçlerinde sivil toplumun gelişmesi hayati önemdedir. Bu çalışma Bosna Hersek’te sivil toplumun gelişmesinde Müslüman Kadın sivil toplum örgütlerinin rolünü ele alacaktır. Öncelikle, Bosna Hersek’te sivil toplumun genel durumu ortaya konularak, teorik bir çerçeve üzerinden söz konusu konuya odaklanılacaktır. Müslüman Kadın sivil toplum örgütlerinin rolü ve fonksiyonlarını inceleyebilmek için sivil toplumun temel fonksiyonları olan, siyasal iktidarın denetimi, siyasal katılım ve seçimlerin izlenmesi, yolsuzlukla mücadele konusunda farkındalığın oluşturulması, karşılıklı anlayış, hoşgörü ve insan haklarının savunulması, medya yoluyla toplumun yurttaşlık haklarının öğretilmesi ve kullanması konusunda bilinçlendirilmesi ve çatışmaların çözüme kavuşturulmasında karşılıklı diyalog süreçlerinin geliştirilmesi gibi konular göz önünde bulundurulmuştur. "Bosna Hersek’te sivil toplumun gelişmesi ve demokratik bir devletin kurulması için Müslüman Kadın sivil toplum örgütlerinin hangi düzeyde sosyo-politik süreçlere müdahil olduğu sorusunun cevabı" çalışmada merkezi bir önem arz etmektedir. Yazar etnoğrafik metodolojiyi kullanarak, "Kadınlar için Nahla 
Eğitim Merkezi” ve "Kewser-Zehra Müslüman Kadınlar Birliği” gibi öncü sivil toplum kuruluşlarındaki kişilerle mülakat yapmıştır.

Anahtar Kelimler: Müslüman Kadın Sivil Toplum Örgütleri, Devlet İnşası, Sosyopolitik, Sivil Toplum ve Bosna Hersek

\section{References}

Badran, M. (2005). "Between Secular and Islamic Feminism/s: Reflection on the Middle East and Beyond," Journal of Middle East Women's Studies, Vol. 1.

Ballinger, P. and Ghodsee, K. (2011). "Socialist Secularism: Religion, Modernity, and Muslim Women's Emancipation in Bulgaria and Yugoslavia, 1945-1991,” Aspasia, Vol. 5.

Belloni, R. (2010). "Bosnia-Herzegovina: Civil Society in a SemiProtectorate," in ed. Thania Paffenholz, Civil Society and Peacebuilding: A Critical Assessment, Boulder, CO: Lynne Rienner Publishers.

Belloni, R. (2010). "Civil Society and Peacebuilding in Bosnia and Herzegovina," Journal of Peace Research, Vol. 38. No. 2

Belloni, R. (2007). State Building and International Intervention in Bosnia, New York: Routledge.

Boli, J. and Thomas G. M. (1997). "World Culture in the World Polity: A Century of International Non-Governmental Organization," American Sociological Review, Vol. 62, No. 2.

Chandler, D. (1998), "Democratization in Bosnia: The Limits of Civil Society Building Strategies," Democratization Vol.5, No.4.

Cockburn, C., Stakic-Domuz, R. and Hubic, M. (2001). Women Organizing for Change: A study of women's local integrative organizations and the pursuit of democracy in Bosnia-Herzegovina, Zenica: Medica Zenica.

Deacon, B. and Stubbs, P. (1998). "International Actors and Social Policy Development in Bosnia and Herzegovina: Globalism and the New Feudalism," Journal of European Social Policy, Vol. 2.

Donia J. R and Fine J. V. A. (1994). Bosnia and Herzegovina: A Tradition Betrayed, London: Hurst and Company. 
Fostering of Civil Society by Muslim Women's... • 119

Edwards, M. (2009). Civil Society, Cambridge: Polity Press.

Haddad, Y. Y. (1998). "Islam and Gender: Dilemmas in the Changing Arab World," in eds. Yvonne Y. Haddad and John L. Esposito, Islam, Gender and Social Change, New York: Oxford University Press.

Helms, E. (2010). "The Gender of Coffee: Women and Reconciliation Initiatives in Post-war Bosnia and Herzegovina,"_Focaal_Journal of Global and Historical Anthropology, Vol. 57.

Helms, E. (2003). "Women as Agents of Ethnic Reconciliation? Women's NGOs and International Intervention in Post-war Bosnia-Herzegovina," Women's Studies International Forum, Vol. 26. No. 1.

Helms, E. (2003). "The "Nation-ing" of Gender? Donor Policies, Islam, and Women's NGOs in Post-War Bosnia-Herzegovina," Anthropology of East Europe Review, Vol. 21, No. 2.

Hemmer, B. (2008). "The Democratization of Peacebuilding: Democratic Exposure and Externally Democratic Ideology of Peacebuilding NGOs in Northern Ireland and Bosnia," Research in Social Movements, Conflicts and Change, Vol. 29.

Imamovic, M. (2006). Bosnia and Herzegovina: Evolution of Its Political and Legal Institutions, Sarajevo: Magistrat.

Interview with Mrs. Sehija Dedovic, Director of Nahla Education Center forWomen http://www.islambosna.ba/Pitanja\%20i\%20odgovori/interviews/2136intervju-sa-sehijom-dedovi-direktoricom-ec-nahla

Interview with Mrs. Sehija Dedovic, Director of Nahla Education Center for Women

http://www.islambosna.ba/Pitanja\%20i\%20odgovori/interviews/2136intervju-sa-sehijom-dedovi-direktoricom-ec-nahla

Interview with Mrs. Sadika Avdic, Director of the Kewser-Zehra Association of Muslim Women, Oslobodjenje September 5, 2010.

Interview with Mrs. Đermana Šeta http://www.miztuzla.com/content/view/452/39/

Kujrakovic, N. (2009). "Osvitanje - The First Muslim Women's Association in Bosnia and Herzegovina," Contributions, Vol. 38.

Lyon, J. (2006). “Overcoming Ethnic Politics in Bosnia” in ed. Martina 
Fischer, Peacebuilding and Civil Society in Bosnia-Herzegovina. Ten Years after Dayton. Münster: Lit-Verlag.

Martens, K. (2002). "Mission Impossible? Defining Nongovernmental Organizations," Voluntas: International Journal of Voluntary and Nonprofit Organizations, Vol. 13, No. 3.

Mahmutčehajić, R. (2000). Bosnia the Good: Tolerance and Tradition, Budapest: Central European University Press.

Mulalić, M. (2009). "Multiculturalism and EU Enlargement: The Case of Turkey and Bosnia-Herzegovina," in ed. Christoph Marcinkowski, The Islamic World and the West: Managing Religious and Cultural Identities in the Age of Globalisation, Berlin: LIT Verlag.

Noel, M. (1994). Bosnia, A Short History, London: Macmillan.

Šeta, Đ. (2011). Zašto marama? Bosanskohercegovačke muslimanke o životu i radu pod maramom, Sarajevo: Centar za napredne studije. Šeta Dj. and Dedovic, S. "Family Structure in the Balkans, Problems and Good Examples," http://www.family-resilience.com/english/wpcontent/plugins/downloads-

manager/upload/The\%20Family\%20Structure\%20in\%20the\%20Balkans, $\% 2$ 0Problems\%20and\%20Good\%20Examples.pdfSejfija, I. (2006). "From the "Civil Sector" to Civil Society?" in ed. Martina Fischer, Peacebuilding and Civil Society in Bosnia-Herzegovina. Ten Years after Dayton. Münster: Lit-Verlag.

Spahić-Šiljak, Z. and Jadranka Anic R. (2009). I vjernice i građanke, Sarajevo: TPO Fondacija i CIPS-Univerziteta u Sarajevu.

Spahić-Šiljak, Z. (2007). "Ženska civilna scena, primjer (de)sekularizacije Bosnie i Hercegovine," in ed. Ahmed Alibasic, Religija i sekularna država, Sarajevo: Fondacija Konrad Adenauer.

Tahirovic, S. (2009). Muslimanska teologinja u BH. društvu- pozicija i uloga," Novi Muallim, Vol. 40.

Velikonja, M. (2003). Religious Separation and Political Intolerance in Bosnia and Herzegovina, Austin TX: Texas University Press. 